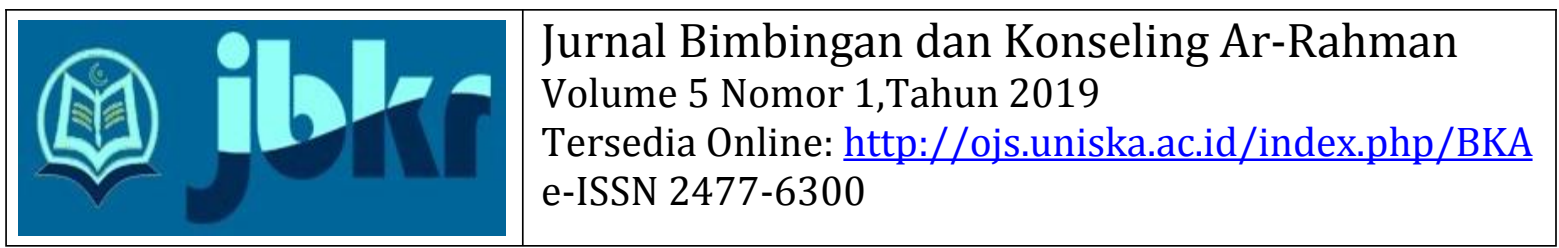

\title{
PENGEMBANGAN NEED ASSESMENT LAYANAN BIMBINGAN KELOMPOK BERBASIS TEKNOLOGI INFORMASIN
}

\author{
Akhmad Rizkhi Ridhani, Zainal Fauzi \\ Universitas Islam Kalimantan Muhammad Arsyad Al Banjari Banjarmasin \\ rizkhi.ridhani@gmail.com/ 085391881999
}

\begin{abstract}
ABSTRAK
Analisis kebutuhan merupakan hal utama dan pertama bagi konselor sekolah untuk menganalisis kebutuh yang dihendaki peserta didik. Namun pada tataran pelaksanaannya konselor kurang efesien dalam memanfaatkan teknologi, dimana kebanyak konselor sekolah masih menganalisis kebutuhan peserta didik secara manual (offline). Padahal teknologi bagi kita merupakan pengetahuan terhadap penggunaan alat dan kerajinan, dan bagaimana hal tersebut mempengaruhi kemampuan untuk mengontrol dan beradaptasi dengan lingkungan alamnya. Maka oleh sebab itu tujuan dari penelitian ini ialah mengembangkan sebuah analisis kebutuhan terhadap layanan bimbingan kelompok berbasis teknologi informasi. Metodologi penelitian yang digunakan peneliti yakni penelitian dan pengembangan (research and development). Dalam pengembangan model ini instrument pengumpul data yang digunakan peneliti yakni; (1) angket, (2) lembar validasi ahli. Hasil penelitian yakni : (a) tersusunya model hipotetik analisis kebutuhan layanan bimbingan kelompok berbasis teknologi informasi hasil revisi dari masukan para ahli yang telah ditetapkan peneliti kriterianya; (b) kekurangan dari model hipotetik ini ialah peneliti hanya menggunakan 5 tahapan pengembangan yakni : (1) studi pendahuluan. (2) perencanaan, (3) pengembangan hipotetik, (4) penelaahan model hipotetik, (5) revisi model hipotetik, sehingga belum dapat dilihat efektifitas model yang dikembangkan peneliti
\end{abstract}

Kata Kunci: Analisis Kebutuhan Layanan Bimbingan Kelompok

\section{ABSTRACT}

Needs analysis is the main and first thing for school counselors to analyze the needs of students. But at the level of implementation the counselor is less efficient in utilizing technology, where most school counselors still analyze the needs of students manually (offline). Though technology for us is knowledge of the use of tools and crafts, and how it affects the ability to control and adapt to their natural environment. So the purpose of this study is therefore to develop a needs analysis of information technology-based group guidance services. The research methodology used by researchers is research and development. In developing this model data collection instruments used by researchers are; (1) questionnaire, (2) expert validation sheet. The results of the study are: (a) the establishment of a hypothetical model of the analysis of the need for revised information technology-based group guidance services from the input of experts who have been determined by the researchers; (b) the shortcomings of this hypothetical model are that researchers only use 5 stages of development namely: (1) preliminary study (2) planning, (3) hypothetical development, (4) hypothetical model review, (5) hypothetical model revision, so that the effectiveness of the model developed by the researcher cannot be seen.

Keywords: Needs Analysis of Group Guidance Services

Dipublikasikan Oleh :

UPT Publikasi dan Pengelolaan Jurnal

Universitas Islam Kalimantan Muhammad Arsyad Al-Banjari Banjarmasin 


\section{PENDAHULUAN}

Kemajuan teknologi informasi saat ini semakin berkembang pesat, khususnya di Indonesia. Teknologi telah mempengaruhi masyarakat dan sekitarnya dalam beberapa cara, seperti halnya informasi yang tadinya sulit diakses menjadi lebih mudah didapat dalam hitungan detik, hal ini tentunya tidak terlepas dari sebuah kemajuan teknologi. Teknologi bagi kita merupakan pengetahuan terhadap penggunaan alat dan kerajinan, dan bagaimana hal tersebut mempengaruhi kemampuan untuk mengontrol dan beradaptasi dengan lingkungan alamnya. Riana (2017) teknologi informasi menekankan pada pelaksanaan dan pemprosesan data seperti menangkap, mentransmisikan, menyimpan, mengambil, memanifulasi atau menampilkan data dengan menggunakan perangkat-perangkat teknologi elektronik terutama komputer. Makna teknologi informasi tersebut belum menggambarkan secara langsung kaitannya dengan sistem komunikasi, namum lebih pada pengolahan data dan informasi.

Layanan bimbingan dan konseling merupakan suatu layanan yang terintegral dalam dunia pendidikan. Pada layanan bimbingan dan konseling terdapat berbagai macam layanan, salah satunya yakni layanan bimbingan kelompok. layanan ini termasuk primadona atau layanan yang paling disukai oleh pesrta didik disekolah. Layanan bimbingan kelompok ini bertujuan untuk mengopimalisasikan potensi yang dimiliki peserta didik dengan memanfaatkan dinamika kelompok yang terjadi saat kegiatan ini berlangsung. Layanan ini menjadi primadona salah satunya dikarenakan topik yang dibahas dalam layanan ini yakni topik yang ringan, seperti diantaranya : (1) cara bergaul, (2) motivasi belajar, (3) mengenal diri, dan lain sebagainya. Wibowo (dalam Ridhani, 2017) menjelaskan bahwa bimbingan kelompok merupakan suatu kegiatan dimana pimpinan kelompok menyediakan informasi-informasi dan mengarahkan diskusi agar anggota kelompok menjadi lebih sosial atau untuk membantu anggota kelompok untuk mencapai tujuan bersama. Lebih lanjut lagi Gibson dan Mitchell (2011: 52) bimbingan kelompok mengacu kepada aktivitas-aktivitas kelompok yang berfokus kepada penyedian informasi atau pengalaman melalui sebuah aktivitas kelompok yang terencana dan terorganisir.

Penyusunan program layanan bimbingan dan konseling disekolah tentunya diawali dengan analisis kebutuhan (need assessment), yang dimana analisis kebutuhan tersebut dapat menggunakan teknik tes maupun non tes. Pada tataran teknis pelaksanaan analisis kebutuhan siswa di sekolah terhadap layanan bimbingan dan konseling, kebanyakan guru bimbingan dan konseling atau konselor sekolah masih menggunakan analisis kebutuhan secara manual, yang dimana konselor sekolah tersebut menyebar printout instrument analisis kebutuhan yang nantinya akan diisi oleh peserta didik, kemudian konselor tersebut mentabulasi hasil isian yang diisi oleh siswa dan menganalisnya secara manual. Namun ada juga yang mentabulasi dan menganalis melalui aplikasi yang bersifat offline seperti ; (1) daftar cek masalah; (2) alat ungkap masalah (AUM-PTSDL); (3) sosiometri, dan lain sebagainya. Melihat fenomena ini peneliti tertarik untuk melakukan pengembangan analisis kebutuhan terhadap layanan bimbingan kelompok berbasis teknologi informasi yang nantinya peserta didik mengisi instrument tersebut secara online.

\section{METODE}

Sesuai dengan fokus permasalahan dan tujuan penelitian, desain penelitian ini menggunakan penelitian dan pengembangan (research and development) Sugiyono (2012: 407). Penelitian pengembangan diarahkan sebagai "a process used to develop and validase aducational product" Borg and Gall (2003 : 271). Produk yang dimaksud adalah need assessment layanan bimbingan kelompok berbasis teknologi informasi.

Borg and Gall (2003:271) langkah-langkah yang seyogyanya di tempuh dalam penelitian pengembangan (research and develompment) meliputi : (1) studi pendahuluan. (2) perencanaan, (3) pengembangan hipotetik, (4) penelaahan model hipotetik, (5) revisi, (6) uji coba terbatas, (7) revisi hasil uji coba, (8) uji coba lebih luas, (9) revisi model akhir, (10) diseminasi dan sosioalisasi.

Pengembangan need assessment layanan bimbingan kelompok berbasis teknologi informasi mengadopsi sepuluh tahapan pengembangan menurut Borg and Gall yang dimodifikasi menjadi lima tahapan, hal ini dilakukan dengan alasan disesuiakan dengan kebutuhan penelitian. lima tahapan tersebut adalah sebagai berikut : (1) studi pendahuluan. (2) perencanaan, (3) pengembangan hipotetik, (4) penelaahan model hipotetik, (5) revisi model hipotetik.

Tabel 1. Intrument Pengumpul Data dan Subyek Penelitian

\begin{tabular}{ccccc}
\hline Instrumen & Jenis Data & Subyek & Tujuan & Analisis \\
\hline Angket & Kuantitatif & $\begin{array}{c}\text { Siswa yang menjadi } \\
\text { subyek layanan } \\
\text { bimbingan kelompok }\end{array}$ & $\begin{array}{c}\text { Untuk mengetahui } \\
\text { masalah yang ingin } \\
\text { dibahas siswa melalui } \\
\text { kegiatan kelompok }\end{array}$ & Deskriptif Kualitatif \\
& & & \\
\hline
\end{tabular}

Dipublikasikan Oleh :

UPT Publikasi dan Pengelolaan Jurnal

Universitas Islam Kalimantan Muhammad Arsyad Al-Banjari Banjarmasin 
Akhmad Rizkhi Ridhani \& Zainal Fauzi Jurnal Bimbingan dan Konseling Ar-Rahman

Volume 5, Nomor 1, Tahun 2019

e-ISSN 2477-6300

\section{HASIL DAN PEMBAHASAN \\ Hasil Penelitian}

Sesuai dengan fokus masalah yang telah dirumuskan oleh peneliti yakni berkenaan dengan pengembangan need assessment layanan bimbingan kelompok berbasis teknologi informasi. Maka disini peneliti menguraikan hasil dari penelitian yang telah dilaksanakan, sebagai berikut :

\section{Hasil Pengembangan Hipotetik}

Adapun konten pengembangan yang dilakukan oleh peneliti disini yakni, sebagai berikut :

Tabel 2. Model Hipotetik Yang Dikembangkan Peneliti

\begin{tabular}{lllllc}
\hline \multicolumn{7}{c}{ ANALISIS KEBUTUHAN LAYANAN BIMBINGAN KELOMPOK } \\
\hline \multicolumn{1}{c}{ Variabel } & Indikator & Sub-Indikator & Deskriptor & $\begin{array}{c}\text { No } \\
\text { Item }\end{array}$ \\
\hline Bimbingan & Identitas & Menjelaskan tentang & 1. Nama & 1 \\
Kelompok & & identitas konseli yang & 2. & TTL & 2 \\
& & akan dilayanani & 3. & Umur & 3
\end{tabular}

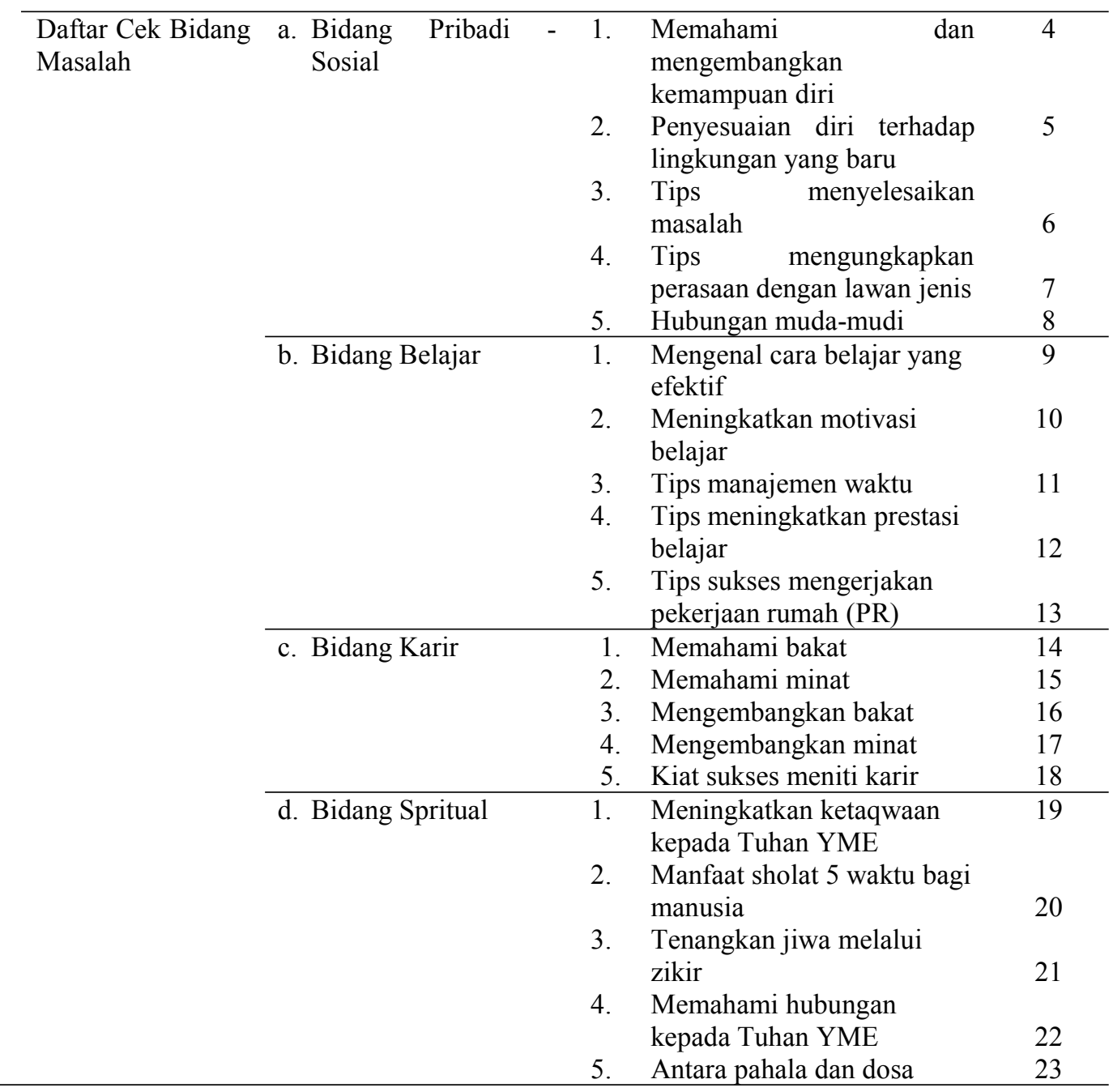

\section{Hasil Penelaahan Model Hipotetik}

Model hipotetik ini ditelaah oleh dua orang ahli bidang bimbingan dan konseling, serta terdapat satu orang praktisi bidang bimbingan dan konseling. Hasil penelaahan dapat dilihat pada tabel di bawah ini :

Dipublikasikan Oleh :

UPT Publikasi dan Pengelolaan Jurnal

Universitas Islam Kalimantan Muhammad Arsyad Al-Banjari Banjarmasin 
Tabel 3 Hasil Validator Ahli Berkenaan Dengan Model Hipotetik Yang Dikembangkan Peneliti

\begin{tabular}{|c|c|}
\hline Validator & Masukan \\
\hline Validator 1 & $\begin{array}{l}\text { Model sudah layak untuk } \\
\text { digunakan, namun perlu } \\
\text { ditambahkan pengantar atau } \\
\text { deskripsi dari layanan } \\
\text { bimbingan kelompok. }\end{array}$ \\
\hline Validator 2 & $\begin{array}{l}\text { Model hipotetik perlu } \\
\text { ditambah berkenaan dengan } \\
\text { informasi konseli yang akan } \\
\text { dilayani, sehingga konselor } \\
\text { mendapatkan data pribadi } \\
\text { konselinya secara utuh. }\end{array}$ \\
\hline Validator 3 & $\begin{array}{l}\text { Tambahkan tanggal pengisian } \\
\text { serta kembangkan lebih dari } 5 \\
\text { item untuk pilihan tema yang } \\
\text { akan di checklist oleh siswa. }\end{array}$ \\
\hline
\end{tabular}

\section{Pembahasan Penelitian}

Adapun hasil revisi model hipotetik yang telah dilakukan peneliti berdasarkan masukan yang diberikan oleh validator, yakni sebagai berikut :

1. Tanggal Pengisian :

2. Identitas
a. Nama :
b. TTL
c. Umur
d. Agama
e. Alamat
f. Kelas
g. No. Hp

3. Bentuk Kegiatan

a. Dalam Ruangan (indoor)

b. Diluar Ruangan (outdoor)

4. Daftar Cek Tema Kegiatan

a. Pribadi-Sosial

1) Memahami dan mengembangkan kemampuan diri

2) Penyesuaian diri terhadap lingkungan yang baru

3) Tips menyelesaikan masalah

4) Tips mengungkapkan perasaan dengan lawan jenis

5) Hubungan muda-mudi

6) Etika berkomunikasi

7) Say No To Drug

8) Hobi dan kesenanganku

9) Peranan diriku dalam lingkup keluarga

10) Aku dan perasaanku

b. Belajar
1) Mengenal cara belajar yang efektif
2) Meningkatkan motivasi belajar
3) Tips manajemen waktu
4) Tips meningkatkan prestasi belajar

5) Tips sukses mengerjakan pekerjaan rumah (PR)

6) Tips belajar mandiri

7) Tips belajar secara berkelompok

8) Memahami mengapa manusia harus belajar dan bekerja

9) Keterampilan membaca dan memahami isi buku

10) Aktivitas BMB3 dalam Belajar: Berpikir, Merasa, Bersikap, Bertindak, dan Bertanggungjawab

c. Karir

1) Memahami bakat

2) Memahami minat

3) Mengembangkan bakat

4) Mengembangkan minat

5) Kiat sukses meniti karir

6) Tips lolos wawancara kerja

7) Hidupku dan tatangan dari sekelilingku

8) Cita-cita yang kuinginkan terhadap pekerjaan

9) Menjadi sosok pemimpin yang ideal

10) Merencanakan karir

d. Spritual

1) Meningkatkan ketaqwaan kepada Tuhan YME

2) Manfaat sholat 5 waktu bagi manusia

3) Tenangkan jiwa melalui zikir

4) Memahami hubungan kepada Tuhan YME

5) Antara pahala dan dosa

6) Berbakti pada orang tua

7) Penyimpangan nilai dan moral

8) Meminimalisir rasa hiri dan dengki

9) Saat aku dan dirimu dipertemukan oleh takdir

10) Membangun generasi bangsa religius

\section{Model Hipotetik Berbasis Teknologi Informasi}

Analisis kebutuhan layanan bimbingan kelompok selama ini masih ada yang menggunakan teknik analisis secara konvensional dalam arti konselor menyebar sebuah angket, kemudian dari hasil isian angket yang diisi oleh siswa tersebut dihitung secara manual. Dari sini peneliti berpijak bahwa yang dilaksanakan oleh guru selama ini kurang efesien karena memerlukan waktu yang panjang terutama dalam analisis.

Model hipotetik berbasis teknologi informasi yang dimaksudkan peneliti disini yakni model yang dimuati oleh kemajuan teknologi informasi, yang dalam hal ini peneliti menggunakan google form. google formulir adalah alat yang berguna untuk membantu anda merencanakan acara, mengirim survei, memberikan siswa atau orang lain kuis, atau

Dipublikasikan Oleh :

UPT Publikasi dan Pengelolaan Jurnal

Universitas Islam Kalimantan Muhammad Arsyad Al-Banjari Banjarmasin 
Akhmad Rizkhi Ridhani \& Zainal Fauzi Jurnal Bimbingan dan Konseling Ar-Rahman

Volume 5, Nomor 1, Tahun 2019

e-ISSN 2477-6300

mengumpulkan informasi yang mudah dengan cara yang efisin.
Berikut tampilan google formulir berkenaan dengan analisis kebutuhan layanan bimbingan kelompok yang dikembangkan peneliti:

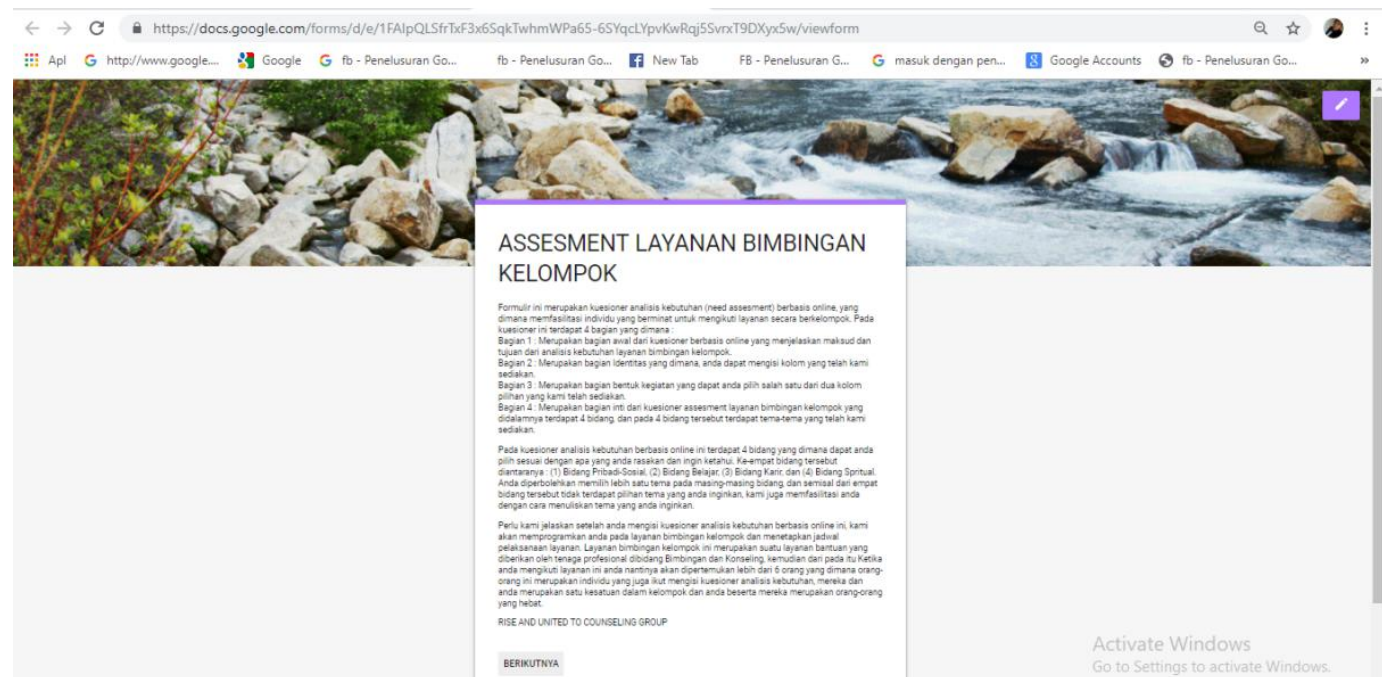

Gambar 1. Tampilan Analisis Kebutuhan Layanan Bimbingan Kelompok Berbasis Teknologi Informasi (google Form)

Keunggulan Model Analisis Kebutuhan Layanan Bimbingan Kelompok Berbasis Teknologi Informasi

Adapun keunggulan dari model analisis kebutuhan layanan bimbingan kelompok berbasis teknologi informasi (google form) yang dikembangkan peneliti, yakni sebagai berikut : (a) Desain tampilan dapat disesuaikan dengan kebutuhan pengelola, (b) Menyimpan data secara aman tanpa takut hilang, rusak, ataupun terkena virus, (c) 50 orang dapat mengerjakan dalam satu berkas dalam satu waktu, setiap perubahan disimpan secara otomatis, (d) Distribusi dan tabulasi online dan real-time, dan (5) hasil tanggapan yang telah diisi oleh reponden dapat dilihat ringkasan keseluruhan (kelompok) dan individual (perorangan) sehingga hal ini dapat mempermudah konselor dalam menganalisis hasil isian responden.

Berikut contoh tampilan tanggapan yang terdapat pada google form yang dikembangkan oleh peneliti, sebagai berikut :

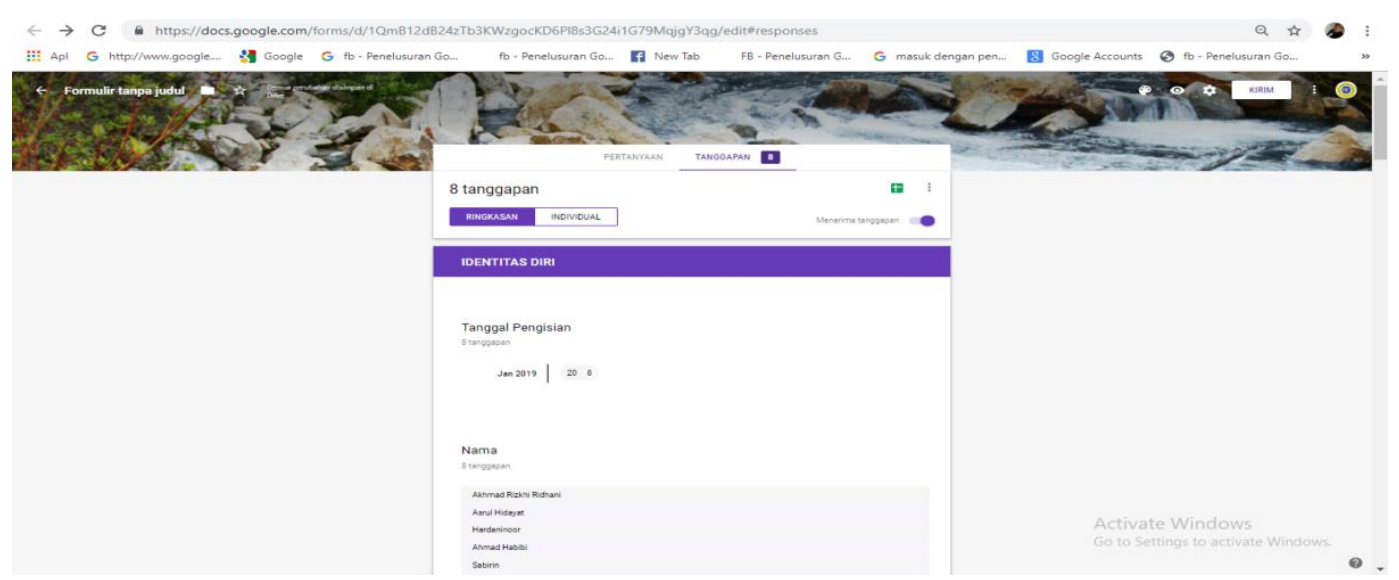

Gambar 2 Contoh Tampilan Tanggapan Yang Telah Diisi Oleh Responden

Dipublikasikan Oleh :

UPT Publikasi dan Pengelolaan Jurnal

Universitas Islam Kalimantan Muhammad Arsyad Al-Banjari Banjarmasin 
Akhmad Rizkhi Ridhani \& Zainal Fauzi Jurnal Bimbingan dan Konseling Ar-Rahman

Volume 5, Nomor 1, Tahun 2019

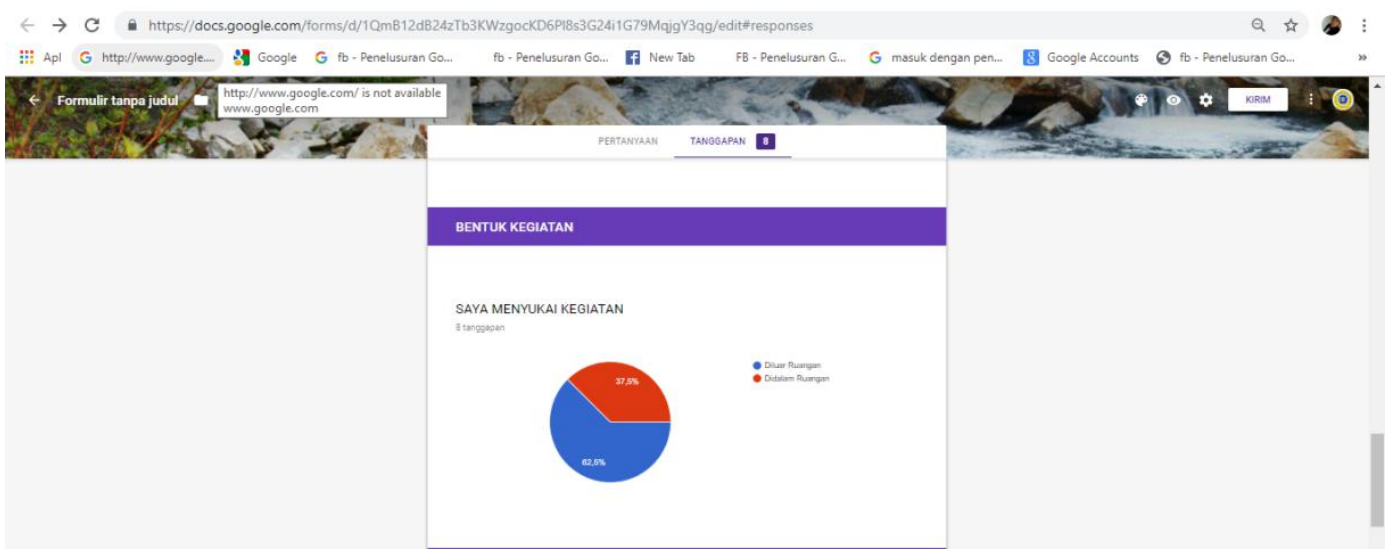

Gambar 3 Contoh Tanggapan Bentuk Kegiatan Yang Terdapat Pada Google Form Analisis Kebutuhan Layanan Bimbingan Kelompok

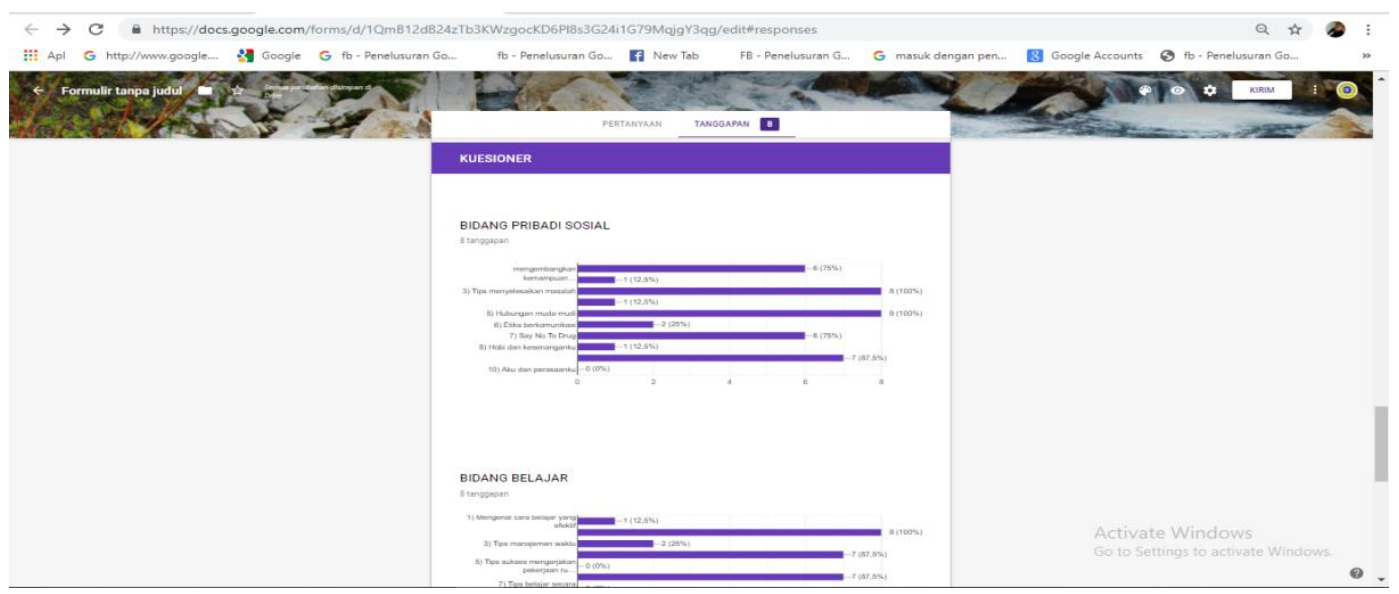

Gambar 4 Contoh Tanggapan Isian Kuesioner Secara Keseluruhan Yang Terdapat Pada Google Form Analisis Kebutuhan Layanan Bimbingan Kelompok

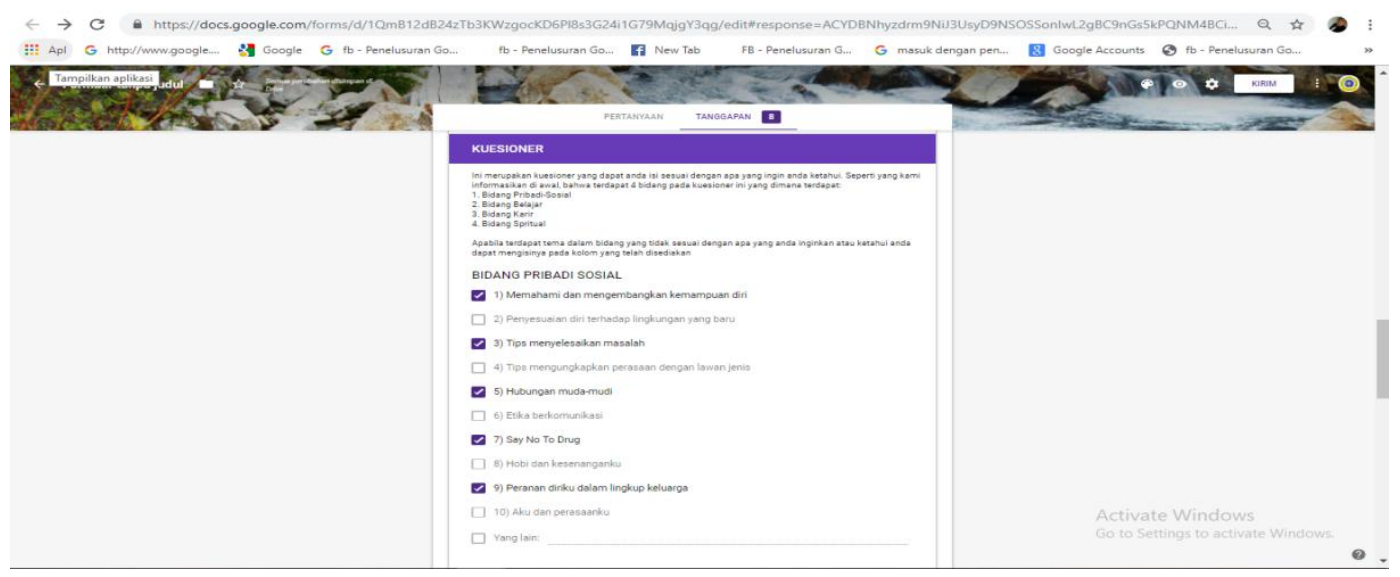

Gambar 5 Contoh Tanggapan Isian Kuesioner Pada Profile Individual Yang Terdapat Pada Google Form Analisis Kebutuhan Layanan Bimbingan Kelompok

Pada gambar 2 dan 4 yang dipaparakan tersebut dapat terlihat jelas hasil dari tanggapan reponden sudah berupa prosentasi, sehingga memudahkan bagi pengelola menganalisis hasil yang telah disebarkan kepada reponden. Kemudian dari pada itu juga pada gambar 5 dapat dilihat bahwa pengelola dapat melihat berkenaan dengan tanggapan responden perindividu.

\section{Dipublikasikan Oleh :}

UPT Publikasi dan Pengelolaan Jurnal

Universitas Islam Kalimantan Muhammad Arsyad Al-Banjari Banjarmasin 
Akhmad Rizkhi Ridhani \& Zainal Fauzi

Jurnal Bimbingan dan Konseling Ar-Rahman

Volume 5, Nomor 1, Tahun 2019

e-ISSN 2477-6300

Hal ini tentunya sangat membantu dan lebih efesien dari segi waktu biaya.

\section{PENUTUP}

Berikut kesimpulan dari hasil penelitian yang dilakukan, yakni sebagai berikut :

1. Tersusunya model hipotetik analisis kebutuhan layanan bimbingan kelompok berbasis teknologi informasi hasil revisi dari masukan para ahli yang telah ditetapkan peneliti kriterianya.

2. Kekurangan dari model hipotetik ini ialah peneliti hanya menggunakan 5 tahapan pengembangan yakni : (1) studi pendahuluan. (2) perencanaan, (3) pengembangan hipotetik, (4) penelaahan model hipotetik, (5) revisi model hipotetik, sehingga belum dapat dilihat efektifitas model yang dikembangkan peneliti.

\section{REFERENSI}

Riyana, Cepi. 2017. Peran Teknologi dalam Pembelajaran.

file:///D:/KARIR\%20ARR/2.\%20PENELITIA N/2.\%20PENELITIAN\%20APBU\%20UNISK A/Anggaran\%202018/2/Bahan/Teknologi\%20I nformasi/PERANAN_TEKNOLOGI_DALAM PEMBELAJARAN.pdf. Diunduh 23 September 2018.

Ridhani, A.R. Bimbingan Kelompok Relegius (Pendekatan Alternatif Membentuk Karakter Anak Islami). Banjarmasin : LP2M UNISKA MAB.

Gibson, R. L, Mitchell, M.H. 2011. Bimbingan dan Konsleing. Yogyakarta : Pustaka Pelajar.

Borg and Gall. 2003. Education Research. New York. Allyn dan Bacon.

Sugiyono. 2012. Metode Penelitian Pendidikan, pendekatan kuantitatif, kualitatif, dan R\&D:Bandung. Alfabeta. 